\title{
Do government formation deadlocks really damage economic growth? Evidence from history's longest period of government formation impasse
}

\author{
Daniel Albalate \& Germà Bel \\ Universitat de Barcelona \& Observatory of Policy Analysis and Evaluation (OAP-UB) \\ (Forthcoming in Governance)
}

\begin{abstract}
Several countries have experienced lengthy periods of government formation deadlock in recent years, as they have sought to form a new government. This study examines whether government formation deadlocks damage a country's economy. To do so, we analyze the case of Belgium, which took a record 541 days to create a post-election government, following the June 2010 federal elections. Employing the synthetic control method, our results show that the Belgium's economy did not suffer an economic toll; on the contrary, Gross Domestic Product per capita growth was higher than would have otherwise been expected. As such, our evidence contradicts frequent claims that long periods of government formation deadlock negatively affect an economy.
\end{abstract}

JEL codes: D72; E02; E65; H1; O43; P48; P52.

Keywords: Government, Governance, Political economy, Synthetic Control Method. 


\title{
Do government formation deadlocks really damage economic growth? Evidence from history's longest period of government formation impasse
}

\begin{abstract}
Several countries have experienced lengthy periods of government formation deadlock in recent years, as they have sought to form a new government. This study examines whether government formation deadlocks damage a country's economy. To do so, we analyze the case of Belgium, which took a record 541 days to create a post-election government, following the June 2010 federal elections. Employing the synthetic control method, our results show that the Belgium economy did not suffer an economic toll; on the contrary, Gross Domestic Product per capita growth was higher than would have otherwise been expected. As such, our evidence contradicts frequent claims that long periods of government formation deadlock negatively affect an economy.
\end{abstract}

\section{INTRODUCTION}

Lengthy government formation processes in parliamentary regimes after a general election are hardly new. While Daniel Diermeier and Peter Van Roozendaal (1998) reported an average of 36 days for the post-election formation of government in a broad sample of European parliamentary countries in the period 1945-1990, some individual countries presented a considerably longer average, for example, Belgium with 57 and the Netherlands with 88 days. Indeed, in that period, the Netherlands went a record 208 days without a fullpowered government in 1977, and Belgium went 106 days in 1987 (Diermeier and Van Roozendaal, 1998; Hooghe, 2012a, Louwerse and Van Aelst, 2013). 
Besides the traditional constraints on government formation in parliamentary democracies (Strøm, Budge, and Laver, 1994), formation deadlocks have become more prominent in recent times in most European countries (Louwerse and Van Aelst, 2013) because of the increasing fragmentation of parliaments (De Winter and Dumont, 2008) and because multilevel governance in the European Union has absorbed some of the core tasks performed by conventional Member States (Bouckaert and Brans, 2012; Deschouwer, 2012; Hooghe, 2012a). As a result, government formation deadlock extended over more than six months in Belgium after the June 2007 election, 10 months in Spain after the December 2015 election, seven months in the Netherlands after the March 2017 election, six months in Germany after the September 2017 election, and three months in Italy after the March 2018 election. However, the record is held by Belgium, which took the not insignificant number of 541 days, following the June 2010 election, to establish a full-powered federal government (Brans, Pattyn, and Bouckaert, 2016).

There is widespread consensus in the economics literature that policy volatility damages economic growth. Alberto Alesina et al. (1996) report lower growth rates in countries during periods marked by a high frequency of government collapse. Likewise, economic growth has been found to be negatively affected by the uncertainty as to whether a government will remain in office after a forthcoming election (Angelopoulos and Economides, 2008). Recent studies by Antonio Fatás and Ilian Mihov (2013), Ari Aisen and Francisco José Veiga (2013), and Henrik Gurkul and Lukasz Lach (2013) provide additional evidence that political instability negatively impacts economic growth. The causal mechanism proposed for this negative effect is that political instability shortens government perspectives, thus disrupting long-term economic policies that might promote better economic performance (Aisen and Veiga, 2013: 152).

The claim is typically made, as well, in the public and institutional debate that the costs associated with government formation deadlock and the absence of a full-powered 
government are transferred to the economy. ${ }^{1}$ Yet, the macroeconomic figures regarding their effects are contradictory. For instance, the real Gross Domestic Product (GDP) growth rate fell in Belgium in 2011 and in Spain in 2016, years in which the two countries faced government formation deadlocks. In contrast, however, in similar situations of government impasse, the real GDP growth rate rose in Belgium in 2007 and in the Netherlands in 2017. The picture is further confused when we compare the performance of these countries' economies during their respective periods of deadlock with the economic performance of other EU countries that were not experiencing situations of government formation impasse at that time.

The key question, though, is not so much whether these countries performed better or worse than their EU counterparts, but whether their respective rates of economic growth were higher or lower than what they would have otherwise been in the absence of government formation deadlock. In this article, we empirically evaluate the economic

\footnotetext{
${ }^{1}$ Examples exist in all countries that have undergone such type of government formation deadlock. This piece by Reuters that elaborates on the king's intervention in the Belgium deadlock because of the threats to the economy provides a good illustration https://www.reuters.com/article/usbelgium-government/belgian-king-due-to-move-on-political-deadlock-idUSTRE7081LV20110109 (retrieved July 26, 2018), and also this later piece by EUobserve https://euobserver.com/political/31822 (retrieved November 29, 2018). For the government formation deadlock in Spain 2015-2016, see for example this warning by Moddy's Analytics that political instability threatening economic growth https://elpais.com/economia/2016/08/08/actualidad/1470683656_203360.html (retrieved
} November 29, 2018). For the most recent long period of government deadlock formation within the EU (Germany in 2017-2018), see chronicle in The New York Times https://www.nytimes.com/2017/11/20/world/europe/germany-merkel-coalition.html (retrieved November 29, 2018). 
performance of Belgium during the longest period of deadlock ever recorded in the formation of a full-powered government following an election. Both because the deadlock duration and the time elapsed since it finished, the Belgium case allows making more relevant and more technically robust the analysis.

To do so, we use the synthetic control method, a statistical method that has received growing attention in recent times having been used to evaluate treatment effects in different policy areas. ${ }^{2}$ Our paper, in dealing with the economic consequences of an exceptional political situation, can be considered similar to the studies of Alberto Abadie and Javier Gardeazábal (2003) on the economic consequences of terrorism in Spain, and which exploited the variability provided by a truce; Abadie, Diamond, and Jens Hainmueller (2015) on the economic cost of German reunification; Kevin Grier and Norman Maynard (2016) on the economic consequences of Hugo Chavez's policies in Venezuela; and Orkideh Gharehgozli, (2017) on the economic effects of international sanctions on Iran.

In this study, we take the GDP per capita growth rate as the best indicator of overall economic performance, and we use the synthetic control method to build an appropriate counterfactual. This enables us to identify and isolate the gap between the actual growth rate in Belgium GDP per capita and the rate at which it would have grown without government formation deadlock. In this way, we contribute to the existing literature by offering what is, to the best of our knowledge, the first evaluation of the effect of a lengthy period of government formation impasse on economic growth. Additionally, we provide original

\footnotetext{
${ }^{2}$ For instance, health and nutrition policies (Bauhoff, 2014; Kreif et al., 2016), energy policies (Munasib and Rickman, 2015; Kim and Kim, 2016), industrial policies (Castillo et al., 2017), local amalgamations (Roesel, 2017), transportation (Percoco, 2015), international sanctions (Gharehgozli, 2017), international trade agreements (Aytug et al., 2015), crime interventions (Saunders et al., 2015) and economic consequences of political administrations (Grier and Maynard, 2016).
} 
insights into the effects of government formation deadlock in Belgium as yet unidentified in the literature.

We organize the rest of the article as follows. The next section reviews the literature on institutions, governance and quality of government, the stream of literature that provides the best theoretical foundations in which to frame our research. Section three reviews the political process that was played out in Belgium after the June 2010 federal elections, which led to the government formation deadlock that was not broken until December 2011. In section four, we provide an analysis of the economic policy implemented by the caretaker government, and report various descriptive statistics on Belgium's economic evolution before, during, and after the deadlock. Section five presents the empirical strategy employed, the synthetic control method, and the results obtained. Finally, we discuss our findings and draw our conclusions.

\section{INSTITUTIONS, GOVERNANCE AND QUALITY OF GOVERNMENT}

While the importance of institutions for fostering economic development has long been recognized (see, for instance, Adam Smith, 1776), Douglas North's seminal studies (1981, 1990) on the effect of institutions on growth paved the way for the scholarly analysis of this relationship (see De Long and Shleifer, 1993; Mauro, 1995; Easterly and Levine 1997; Easterly, 2001). Following an influential paper by Daron Acemoglu, Simon Johnson and James Robinson (2001) linking institutions and development, the view that institutions are a primary determinant of economic performance became widely accepted (Economides and Egger, 2009). Subsequently, the role of institutions was incorporated into the core of mainstream economic theory (Jones and Romer, 2009) and much empirical evidence has been reported to illustrate its importance (i.e. Knack and Keef, 1995; Hall and Jones, 1999; 
Redek and Susjan, 2005; Beck and Laeven, 2006). ${ }^{3}$ Based on this evidence Adnan Efendic, Geoff Pugh and Nick Adnett (2011) conducted a meta-regression analysis on the relationship between institutions and economic performance, and found indications of a sizeable, positive effect of institutions on output levels.

Among studies of this relationship, increasing attention has been paid to the analysis of governance and the quality of government. Daniel Kaufmann, Aart Kraay and Pablo ZoidoLobatón (2000: 10) define governance as: "the traditions and institutions that determine how authority is exercised in a particular country. This includes (1) the process by which governments are selected, held accountable, monitored, and replaced; (2) the capacity of governments to manage resources efficiently and formulate, implement, and enforce sound policies and regulations; and (3) the respect of citizens and the state for the institutions that govern economic and social interactions among them."

Likewise, Avinash Dixit (2009: 5) defines economic governance as the structure and functioning of the legal and social institutions that support economic activity and economic transactions, but he stresses that governance should not be confused with government. Thus, while government is clearly an important element of governance, in almost all countries other social institutions of economic governance (whether public or private) also exist. A further distinction has been drawn here between private- and public-order institutions and is discussed in detail by Sheilagh Ogilvie and A. W. Carus (2014), while Acemoglu and Johnson (2005) emphasize the central role played by public-order institutions in economic growth.

The analysis of the effect of quality of government on economic performance has been heavily influenced by the work of Rafael La Porta et al. (1999), in which theories of

\footnotetext{
3 It is worth noting that other influential studies raise questions about the direction of the causal relationship between institutions and economic development and sustain that it is good policies and economic growth what promotes institutional improvement (i.e. Sachs, 2003; Glaeser, et al, 2004)
} 
institutional development are revised, and measures of government performance are proposed. Throughout the present century, the quality of government has gained increasing relevance not only in the literature on economic performance but also in that of other areas of the social sciences (Adserà, Boix, and Payne, 2003; Rothstein and Teorell, 2008; Alesina and Zhuravskaya, 2011; Acemoglu and Robinson, 2012; Rothstein, Samanni, and Teorell, 2012; Fortunato and Panizza, 2015; Rodríguez-Pose and Di Cataldo, 2015; Rodríguez-Pose and Garcilazo, 2015). Indeed, in recent years, various international organizations and research institutions have built and disseminated databases containing quality of governance indicators. Prime examples include the World Bank's Worldwide Governance Indicators and the Quality of Government Index created by the University of Gothenburg.

The aim of our paper is to evaluate the economic effects of government formation deadlocks and, more specifically, their impact on GDP per capita growth, which we contend is the best indicator of an economy's overall performance. To do so, we adopt the empirical operationalization proposed by La Porta et al. (1999), on the grounds that it provides useful insights into the economic effects of the quality of government.

To evaluate economic performance, an initial group of measures focuses on government intervention in the economy and, more specifically, on the quality of regulation and protection of property rights. La Porta et al. (1999) employ an additional dimension for evaluating good government: namely, that of government efficiency and the quality of bureaucracy. In a similar vein, William Keech and Michael Munger (2015: 11) emphasize meritocracy, recruitment and promotion, and autonomy as requirements for high quality administrative institutions. Based on the dimensions of quality of government proposed, La Porta et al. (1999: 234) subsequently provide a set of indexes to measure government intervention (including quality of business regulation, tax rates, survey scores on corruption, bureaucratic delays, etc.). A synthesis of proxies for quality of government has been proposed by Nicholas Charron and Víctor Lapuente (2013) and Charron, Levis Dijkstra and Lapuente 
(2014). These include low levels of corruption, rule of law, government effectiveness, and protection of property rights. Frequent use of all these dimensions has been made in analyzing the effects of quality of government (Holmberg, Rothstein and Nasiritousi, 2009). Most indicators of quality of government are closely connected to impartiality in the exercise of power: a government must treat its citizens equally (Rothstein and Teorell, 2008). Because those indicators are highly correlated, quality of government can be regarded as a general characteristic of countries (Tabellini, 2008). That is, some territories (jurisdictions) have a systematically higher quality of government than others.

It should be noted that Barbara Vis, Jaap Woldendorp, and Hans Keman (2012) draw a subtle distinction between government policy performance and economic performance. We believe this distinction to be useful for our purposes here, as it clearly recognizes that economic performance depends on factors that extend well beyond government policies. According to the evidence discussed above (Alesina et al, 1996; Fatás and Mihov, 2013; Aisen and Veiga, 2013; Gurkul and Lach, 2013), political instability translates into political volatility, thus damaging economic growth. However, in countries with good governance, and above all with a high quality of government, political instability (in the form, for example, of protracted government formation deadlocks) does not automatically translate into political volatility, because long-term, pro-growth economic policies are not necessarily disrupted. Hence, our main hypothesis is that the quality of government in Belgium may have prevented political instability from damaging the country's economic growth. Furthermore, we hypothesize that Belgium's multi-level governance structure (i.e. regional, federal, and European) has meant that its political stability at both regional and supranational levels has served to counterbalance the effects of political instability at the federal level.

\section{BELGIUM'S RECORD-BEATING GOVERNMENT FORMATION DEADLOCK (2010-2011)}


The Belgian general election held on June 13, 2010, resulted in a highly fragmented political landscape, with 11 different parties winning seats in the House of Representatives. Table 1 records the names of the parties elected and the percentage of votes each received, and compares these results with the number of seats they obtained in the previous federal election.

\section{(insert table 1)}

The parties forming the pre-election government coalition $(\mathrm{CD} \& \mathrm{~V}, \mathrm{MR}, \mathrm{PS}$, Open_VLD, and CDH) obtained a total of 83 seats, down from 90 in the previous parliament. While their 2010 result continued to represent over half the Chamber (150 seats in total), it should be recalled that the election had actually been provoked by Open_VLD resigning from government (Abts, Poznyak, and Swyngedouw, 2012). Thus, the incumbent parties in fact controlled just 70 seats, less than half the Chamber.

The high degree of political fragmentation inevitably hampered negotiations to form a new cabinet. Of the 150 representatives, the leading party (17.4\% of votes) controlled just 27 seats. A further six parties had more than 10 seats, but only one of these had more than 20. In terms of 'effective' number of parties $(\mathrm{Na})$ and Fractionalization $(\mathrm{Fa})$ in Markku Laakso and Rein Taagepera (1979), for $a=2$, the 2010 election yielded Ns (Seats) of 8.4 and $\mathrm{Nv}$ (votes) of 10.1. The corresponding F-indexes are Fs of 0.88 and $\mathrm{Fv}$ of 0.90 . Thus, the effective numbers of parties after the 2010 election are more than double the last indexes available for Belgium in Laakso and Taagepera (1979, p. 10, table 1).

The situation was complicated still further because of the difficulty in complying with various unwritten rules of government formation [including, for example, 'linguistic cleavage', and the need for regional parties belonging to the same broad political family to be in government (Deschouwer, 2009)]. Thus, fragmentation combined with ideological differences and increasing tensions between the Flemish and Walloon regions impeded 
government formation. The leader of NV-A and winner of the elections, Bart de Wewer, was designated by King Albert to take the initiative in government formation (formateur), but he resigned in early July 2010 (Abts, Poznyak and Swyngedouw, 2012). He was followed by Elio Di Rupo, leader of the Socialist Party in the French-speaking Community of Belgium, but the impossibility of reaching a consensus led to his resignation in early September. ${ }^{4}$

The presidents of the Belgian Senate and of the House of Representatives were then asked by the king to mediate between the political parties, but they did not reach an agreement, and in early October 2010 negotiations between the main parties broke down. New mediators were appointed while the king asked the former prime minister to stay in office as a caretaker government with limited powers. The two main issues blocking any agreement were the model of funding for the bilingual region of Brussels and the regions, and certain institutional questions affecting the Senate and the electoral district of BrusselsHalle-Vilvoorde (Abts, Poznyak, and Swyngedouw, 2012). The latter was the subject of a highly sensitive dispute between Walloon parties (that wanted it to remain as a single district) and Flemish parties (that wanted the district to be split in two). ${ }^{5}$

In May 2011, negotiations were revived once more with the designation of Di Rupo (PS) as formateur. In October, an agreement for institutional reform was finally reached, but the obstacles to the formation of a new government only disappeared at the end of November. A final agreement was reached on 5 December 2011, with a new fragile six-party coalition led by Di Rupo (PS) as Prime Minister, and formed by Socialist, Christian Democrat and Liberal parties from both regions. And so ended the longest ever period of government

\footnotetext{
${ }^{4}$ Di Rupo tendered his resignation on August $29^{\text {th }}$, but the king refused to accept it and asked him to continue with his efforts to break the deadlock.

${ }^{5}$ It coincides with the bilingual (French and Dutch) administrative district of the Brussels-Capital region and the surrounding Dutch-speaking area.
} 
formation deadlock in a democratic, parliamentary regime -541 days of deadlock and 590 without a full-powered government (Bouckaert and Brans, 2012; Brans, Pattyn and Bouckaert, 2016)- surpassing the 353 days of government deadlock in Cambodia 2003-04.

\section{ECONOMIC POLICY AND ECONOMIC PERFORMANCE UNDER THE CARETAKER GOVERNMENT}

\section{Economic policy under the caretaker government}

Immediately following the resignation of the government in April 2010, government services issued two circulars specifying the conventions and guidelines for the caretaker government ${ }^{6}$ [26 April and 7 May, 2010 (Brans, Pattyn, and Bouckaert, 2016)]. The government formation deadlock greatly diminished the capacity of this caretaker government from intervening in the economy compared to the powers enjoyed by an elected government. Thus, the 2011 budget was not in fact approved until May 2011; and, in the meantime, the caretaker government had to pass regular resolutions prolonging the 2010 budget on a month to month basis, in keeping with the system known as 'provisionary 12th's', whereby government departments continued to receive the same budgetary allocations received in the previous year, generally for three-month periods (Bouckaert and Brans 2012; Brans, Pattyn, and Bouckaert, 2016). Day-to-day affairs were overseen by this temporary caretaker government, but no major decisions could be taken with regard to economic policy, and more specifically concerning the budget or national debt.

\footnotetext{
${ }^{6}$ The concept of a 'caretaker government' had emerged immediately after the II World War [see Davies (1946); Morgan (1946); Woolbert, 1946)], and designates the government that deals with ordinary issues in transitory periods caused by the resignation or destitution of a government, or an election in parliamentary regimes, until a new government is elected by Parliament. Caretaker governments are understood to be responsible solely for 'ordinary' issues, and should not adopt any decisions likely to constrain the options of the future government.
} 
The absence of a new federal budget meant some automatic savings, given that budgeting is typically done on the basis of the previous year's budget with an inflation adjustment (Bouckaert and Brans, 2012; Hooghe, 2012a); however, the government did not implement any structural financial measures (OECD, 2011: 31). According to Geert Bouckaert and Marleen Brans (2012: 174), the caretaker government did, however, have to face a number of pressing matters, such as complying with international defense commitments (i.e. NATO operations in Libya), introducing migration legislation, and contributing to EU measures to support the Euro, etc. But no major structural policy reforms were implemented (Troupin, Steen, and $\underline{\text { Stroobants, }}$ 2015) that might have affected critical issues in the domain of pension systems, social affairs, energy supply and environment, employment and labor market, and competitiveness (Brans, 2012; Brans, Pattyn and Bouckaert, 2016).

However, with the passing months, even though the caretaker government was appointed to do only 'what is necessary for the country' (Hooghe, 2012a; Deschouwer, 2012), the understanding of just what was necessary expanded in more than one domain. Thus, the government approved a new budget in March 2011 (the first time this had ever occurred under a caretaker government) and the new 2011 Budget was passed by Parliament in May. These new budget provisions served as the basis for the Belgian Stability Program 2011-2014 (FGB, 2011), submitted to the European Commission (EC) in April 2011. In this program, the Belgian Government committed itself to a GDP deficit of 3.6 percent in 2011, and less than 3 percent in 2012. However, budget adjustments were below expectations. The European Council (2011, points 8 \& 9) advised Belgium to increase its fiscal consolidation efforts. Similarly, in fall 2011, the EC made further calls for budgetary discipline from the Member States, but the caretaker government argued that implementing EU demands and avoiding penalties meant adopting measures that lay beyond its designated authority.

These events ran in parallel with increasing concerns in the financial markets, alarmed by the lack of progress made in reducing public deficit. In November 2010, Belgium was 
added to the list of countries, made up of Portugal, Spain and Italy, which it was feared could be heading for a financial crisis. This had an impact on the government bond market. The risk premium steadily increased after April 2011, peaking in November 2011. The spread on Belgian 10-year bonds (relative to the German Bund) rose to more than 360 basis points, while the spreads on French and Dutch bonds reached about 190 and 60 basis points, respectively (European Commission, 2012). Given the high, and increasing, level of public debt, the Belgian public sector remained vulnerable to market pressures (European Commission, 2012). By late November 2011, this pressure from the financial markets seems likely to have affected the negotiating parties and political elites (Devos and Sinardet, 2012), and a short time after (5 December 2011) a new government was formed, much to the relief of the financial markets.

\section{Belgium GDP performance during the political crisis}

Despite the government formation deadlock and the limited powers of the caretaker government, Belgium's economic performance does not appear to have suffered much. If we observe the GDP growth rate (Figure 1), Belgium's performance between 2010-2014 was slightly higher than the EU average, and better than the euro area average, though in the latter case only until 2013.

\section{(Insert Figure 1)}

However, this comparison tells us only how Belgium's performance compared with that of the other countries of Europe, but it offers no insights as to how it might have performed had a full-powered government been in office. For policy evaluation purposes, what is relevant is not how Belgium performed in comparison with other countries, but rather how much better or worse it would have performed in the absence of government formation deadlock. Given that this outcome cannot be observed, it constitutes our counterfactual. Indeed, its apparently better comparative performance in Europe could be hiding detrimental economic consequences of its institutional crisis. 
The following section describes the empirical strategy we adopt to construct the counterfactual so that we can assess how the government formation deadlock affected economic growth in Belgium.

\section{EMPIRICAL STRATEGY}

The goal of our empirical study is to assess the impact that the delay in government formation had on Belgium's economic growth. The effect of the treatment - that is, the 2010 federal elections - is estimated using the synthetic control method (Abadie and Gardeazábal, 2003; Abadie, Diamond, and Hainmueller, 2010, 2015). This policy evaluation tool is especially appropriate for comparative case studies and specifically designed to evaluate the treatment effects of major events impacting units of analysis that are often aggregate entities, such as countries, for which no suitable single comparisons are available. Hence, the method is suitable for evaluating exceptional political situations, as illustrated in the seminal paper by Abadie and Gardeazábal (2003), and in the more recent studies of Abadie, Diamond, and Hainmueller (2015), Grier and Maynard (2016) and Gharehgozli (2017).

The method is also appropriate for use if there exists a donor pool of control units that are unaffected by the event - as is the case in our setting - given that we are studying a political situation limited to Belgium. Furthermore, using a weighted average of units as a comparison precludes the type of model-dependent extrapolation on which regression results are often based (King and Zeng, 2006).

Table 2 reports the pretreatment values of several variables typically associated with a country's growth potential. As in the aforementioned literature, a comparison is made between the evolution in Belgium's GDP per capita growth rate and that of a weighted combination of EU countries selected to resemble the characteristics of the Belgian economy before the government formation deadlock. This weighted average of values for these other EU countries is conceptualized as a "synthetic" Belgium without the government formation 
deadlock experienced between 2010 and 2011, against which the values for the "real" Belgium can then be compared. The donor pool used in the comparison includes a sample of the EU-28 countries. Unfortunately, Croatia, Cyprus and Luxembourg had to be excluded given the amount of missing data for some of the key predictors used in the analysis.

\section{(Insert table 2)}

As described in Abadie, Diamond, and Hainmueller (2015), the difference between the preintervention characteristics of the treated unit and the synthetic control is given by the vector $\mathrm{X}_{1}-\mathrm{X}_{0} \mathrm{~W}$, where $\mathrm{X}_{1}$ is the vector of features of the treated unit, $\mathrm{X}_{0}$ the vector of features of the control units, and W a weight matrix. Here, we select the synthetic control, $\mathrm{W}^{*}$, which minimizes the size of this difference during the pretreatment period. Abadie and Gardeazábal (2003) and Abadie, Diamond, and Hainmueller (2015) choose W* as the value of $\mathrm{W}$ that minimizes $\sum_{m=1}^{k} v_{m}\left(X_{1 m}-X_{0 m} W\right)$, where $\mathrm{v}_{\mathrm{m}}$ is a weight that reflects the relative importance assigned to the $m$-th variable when the discrepancy between $\mathrm{X}_{1}$ and $\mathrm{X}_{0} \mathrm{~W}$ is measured.

The implementation of this method confirms that the synthetic unit is, in fact, a better comparison unit than the pool of potential donor countries, as it resembles the treated unit more closely in terms of predictors (Table 2). Overall, this suggests that synthetic Belgium provides a better point of comparison than the population-weighted average of the pool.

The synthetic unit comprises the unequal contributions of the control units. Table 3 presents the weight matrix for the donor pool, where the synthetic weight is the country weight assigned to each country. When the algorithm is applied to create a synthetic control, a control is obtained made up of the four main contributors, that is, the Netherlands $(55.8 \%)$, Spain (19.6\%), France (18.1\%) and the United Kingdom (5.7\%). Italy also plays a role here, 
but only a minor one $(0.1 \%)$. The rest of the countries do not contribute to the synthetic unit. When using this control to predict Belgium's GDP per capita from 1999-2009, the root mean squared percentage error (RMSPE) is 0.017 , or less than 2 percent.

\section{(Insert table 3)}

\section{RESULTS}

Figures 2 and 3 report the main results. Figure 2 shows how the path taken by synthetic Belgium's GDP per capita closely resembles that taken by real Belgium's GDP until 2009, that is, before the 2010 turning point. The credibility of a synthetic control depends upon just how well it tracks the treated unit's characteristics and outcomes during the pretreatment period. Here, the synthetic Belgium control appears to provide good tracking. Interestingly, after 2010, the performance of real Belgium is better than that of its counterfactual, the gap with respect to the synthetic comparison unit increasing until 2013. This would indicate that the government formation deadlock did not undermine the growth of the Belgian economy, but, on the contrary, it had a positive effect, at least for GDP per capita.

\section{(Insert Figure 2)}

Figure 3 shows more specifically the gap between both units as evidence of an increasing positive difference initiated in 2010 - the differences between both units being computed over time.

\section{(Insert Figure 3)}

Table 4 shows that real Belgium's GDP per capita in 2010 was about 3.3\% higher than its counterfactual, with the greatest difference with respect to the synthetic GDP per 
capita being recorded in 2013 , when it was $6.6 \%$ higher. This result seems to indicate that the better performance of real Belgium lasted for approximately three years. After 2013, the difference between the two units stopped increasing.

\section{(Insert table 4)}

\section{Placebo tests}

The "in time" placebo treatment is considered as having taken place in Belgium in 2006, just before the 2007 world economic and financial downturn and also just before the previous federal elections, held on 10 June 2007. The same empirical strategy is applied, but on this occasion we optimize the synthetic control method for a pre-treatment period that runs from 1999 to 2005, with an expected treatment effect in 2006. The resulting trajectory for this new placebo test is shown in Figure 4. As expected, we are unable to identify any significant gap between the paths taken by real Belgium and this new synthetic Belgium. The pre/post GDP per capita paths do not present any differences.

\section{(Insert figure 4)}

The "in space" placebo tests consider all the units in the donor pool, and we then run the same optimization model but treating each of them as having been treated iteratively; that is, as if there had been government formation deadlock in 2010. We retain those simulations that successfully predicted the pre-intervention period between 1999 and 2009. To filter this goodness of fit, we use the standard, but demanding, rule that excludes those with an RMSPE twice the size of that obtained for the real case of Belgium. Thus, those countries presenting an RMSPE greater than 3.3\% are excluded when we compare the base model to the best placebos. The remaining countries are more likely to report a higher placebo effect and are, as such, better candidates for inclusion in the placebo distribution (Gharehgozli, 2017). 
Figure 5 plots the trajectories for these placebo tests and, as expected, shows Belgium to be an outlier. These findings lend support to the contention that the effect obtained for Belgium is attributable to the government formation deadlock and the absence of full-power, government-led discretionary policies.

\section{(Insert Figure 5)}

\section{DISCUSSION}

The results obtained from our analysis using the synthetic control method indicate that the rate of growth of Belgium's GDP was higher during the period of government formation deadlock than it would have been in the same period with a full-powered government in office. Most strikingly, in 2011, following almost a whole year without a full-powered government, we record the highest relative increase in the gap between what actually happened in the Belgium's economy and our counterfactual, a regular non-deadlock year. After 2012, the difference between the real Belgium and synthetic Belgium ceases to grow, and the gap narrows in the following years.

While our analysis is not intended to explain the rate of growth experienced by the Belgium's economy during the period of government formation deadlock, we discuss causal mechanisms that might have prevented the translation of political instability into policy volatility, thus avoiding negative effects on economic growth. Below we discuss several circumstances that may explain why the government formation deadlock did not damage Belgium's economic growth: (1) Not having a full-powered government was not the same as having no government at all; (2) The effect of multilevel governance in Belgium; (3) The quality of government in Belgium; and (4) The effects on GDP from delaying fiscal consolidation efforts.

During the 18 months of deadlock, a caretaker government was always in place. This government was empowered to take all decisions in relation to ordinary matters, and urgent 
matters when so needed - in particular those related to the EU and the international arenas (Bouckaert and Brans, 2012; Brans, Pattyn, and Bouckaert, 2016)]. According to Bouckaert and Brans (2012: 174), as the deadlock became more entrenched, the scope of just what the caretaker government could do grew. For example, a new budget was approved by this government in March 2011 (and subsequently in May by Parliament). As such, political instability was never to express itself as policy volatility, and thus economic uncertainty and instability. According to our first hypothesis above, because the government formation deadlock did not translate into policy volatility, economic growth was not negatively affected. Moreover, by the time financial instability at the EU level had become extreme (that is, by late fall 2011), a full-powered government was then in office. Thus, not having a full-powered federal government did not mean the country was without any kind of federal government (Devos and Sinardet, 2012; Hooghe, 2012b).

Furthermore, the absence of a full-powered government at the federal level in Belgium must be understood within the broader context of Belgium's multi-level governance structure. Belgium's federal system assigns a considerable number of functions and powers to the communities and regions, above all to Flanders and Wallonia. The Belgian regions, for example, play a key role in the provision of basic collective goods (education, health, infrastructure, etc.). Thus, given the way in which Belgium's federal structure and party system are set up, the political instability caused by deadlock at the federal level did not translate into political instability at the regional level (Bouckaert and Brans, 2012). Furthermore, coordination between federal and regional governments had been fueled by the requirements of participation in EU institutions (Beyers and Bursens, 2006). The policymaking process at the EU level does not differentiate between full-powered or caretaker governments in the Member States, and as such the Belgium's caretaker government had to meet its obligations with EU governance, including coordination with the regions (Deschouwer, 2012). Hence, consistent with our second hypothesis above, political stability 
at the regional and supranational levels palliated the effects of political instability at the federal level.

Quality of government indicators comprise dimensions that extend beyond the work of the executive, especially in a situation where a government's powers are limited to overseeing ordinary matters. As discussed above, economic governance includes, among others, such dimensions as government effectiveness and control of corruption. According to the Worldwide Governance Indicators (WGI-WB) of the World Bank for 2010 (the year when the government formation deadlock began), Belgium ranked $10^{\text {th }}$ out of the $28 \mathrm{EU}$ countries, indicating it had better governance than most of the Member States. More importantly, Belgium ranked 7/28 in terms of Government Effectiveness, Voice and Accountability, and 9/28 in terms of Control of Corruption (however, it occupied a fairly mediocre position on Regulatory Quality - 14/28). Similarly, Belgium ranked better than average $(11 / 28)$ on the European Quality of Government Index (EQI-QofG) constructed by the Quality of Government Institute (University of Gothenburg) for 2010. Elsewhere, the 2010 Global Competitiveness Report (GCR-WEF) of the World Economic Forum, which provides information on key indicators for quality of governance, reported similar results for corruption as the WGI-WB, while Belgium ranked 11/28 for trust in politicians, and 12/28 for protection of property rights and judiciary independence. ${ }^{7}$ Thus, while Belgium does not top the rankings of quality of governance in the European Union (reserved for the

\footnotetext{
7 WGI-WB data can be consulted at www.govindicators.org (see also specific information for EU countries in 2010 in Kaasa, 2013); data for EQI-QofG for 2010 are available at https://qog.pol.gu.se/data/datadownloads/qog-eqi-data; data from GCR-WEF for 2010 are available at http://www3.weforum.org/docs/WEF GlobalCompetitivenessReport 2010-11.pdf
} 
Scandinavian countries), its position is above average in terms of most key indicators. ${ }^{8}$ Therefore, the country's relatively good quality of governance seems likely to have played a role in preventing the transfer of political instability into the economic arena and generating volatility and uncertainty.

Turning to the public finance dimension, it is perhaps worth recalling that the fact that Belgium did not have a new federal budget until May 2011 could have meant some automatic savings, given that transitory budgeting procedures would not have updated for inflation (Bouckaert and Brans, 2012; Hooghe, 2012a). However, these automatic savings, which may have acted as a contractive fiscal policy in 'regular' times, occurred amid a sharp economic and financial crisis in the EU, which means that limiting fiscal consolidation to these automatic changes served as an expansive fiscal policy, at least in comparative terms. Indeed, it has been widely documented that the government did not implement any structural financial measures (Brans, 2012; Brans, Pattyn, and Bouckaert, 2016; OECD, 2011; Troupin, Steen, and Stroobants, 2015). Furthermore, the government failed even to meet its commitment with the European Commission to reduce the country's GDP deficit to 3.6 percent in 2011 (FGB, 2011). According to Eurostat data, Belgium's public deficit stood at $4.1 \%$ of GDP in 2011, rising from $4.0 \%$ in 2010. It is reasonable to think that government formation deadlock undermined the government's ability to implement a more intense deficit reduction and, as such, fiscal adjustment was postponed. ${ }^{9}$

\footnotetext{
8 A specific issue related to good governance is the quality of bureaucracy, as emphasized in La Porta et al. (1999) and Keech and Munger (2015). See Brans (2012) for an analysis of the role of civil servants and public managers in guaranteeing the continuity of government operations.

${ }_{9}^{9}$ Detailed information on fiscal consolidation measures employed in Belgium between 2009 and 2014 is offered in Steve Troupin, Trui Steen, \& Jesse Stroobants (2015: 466-467)
} 
Drawing on Eurostat data for EU countries in 2011, we computed Belgium's public deficit in that year in a scenario in which its financial consolidation had been as intense as in the euro zone as a whole. We found that its public deficit would have been $2.8 \%$ of GDP as opposed to $4.1 \%$. Furthermore, we computed Belgium's deficit as if it had behaved in line with the donor pool of countries in our synthetic control analysis (see Table 3 above): we obtained a public deficit of $3.6 \%$ (compared to the actual 4.1\%). These results support the conclusion that the government formation deadlock slowed the pace of fiscal consolidation and that this is, in all likelihood, one of the factors that explains Belgium's relatively higher GDP per capita growth rate. ${ }^{10}$

\section{CONCLUDING REMARKS}

Our findings in this article run counter to frequently made claims that political deadlocks have an economic cost. Following implementation of the synthetic control method, our study shows that - in the case of Belgium, at least (the country to date recording history's longest period of government formation impasse) - not only was there no evidence of any economic deterioration, but the country's economic growth was actually higher than that of its counterfactual.

During the period of government formation deadlock, a government did exist - albeit not a full-powered government - that responded to all matters of urgency, and which expanded its scope of action as the period of impasse lengthened. Parallel with this, multilevel governance in Belgium was an additional factor that diminished the effects of the deadlock.

\footnotetext{
${ }^{10}$ A comparison with the countries in the donor pool shows that public deficit as \% of GDP in 2011 grew only in Belgium and Spain, and that the growth rate was relatively higher in Belgium. In all the other countries (Netherlands, France, United Kingdom and Italy), public deficit as \% of GDP in 2011 decreased by between 12 and 25\% from 2010. Detailed computations are available upon request.
} 
A further factor that ensured political instability and uncertainty did not impact the economy was the relatively high quality of most of the dimensions considered key for economic governance. Thus, robust, efficient institutions, beyond government, played a positive role in protecting the economy from the difficulties of government formation deadlock.

Our study further suggests that delays in fiscal consolidation may account for the fact that economic growth was higher than might otherwise have been expected. However, while our analysis allows us detecting this effect in the short term, the scope of the study means we can make no long-term forecasts in this regard.

The structure and levels of government, the separation of powers, and economic governance are unique to each country, which means we cannot generalize our findings regarding the absence of economic deterioration resulting from government formation deadlock in Belgium. Future research needs to analyze other countries that have experienced similar (although shorter) periods of impasse to determine the role played by idiosyncratic governance characteristics, and to ascertain whether any common patterns emerge from different government formation deadlock events.

\section{REFERENCES}

Abadie, Alberto, Diamond, Alexis \& Hainmueller, Jens, 2010. Synthetic control methods for comparative case studies: Estimating the effect of California's tobacco control program. Jounral of the American Statistical Association 105 (490), 493-505.

Abadie, Alberto, Diamond, Alexis \& Hainmueller, Jens, 2015. Comparative politics and the synthetic control method. American Journal of Political Science 59 (2), 495-510.

Abadie, Alberto \& Gardeazabal, Javier, 2003. The economic costs of conflict: A case study of the Basque country. American Economic Review 93 (1), 112-132.

Abts, Koen, Poznyak s Dmitriy \& Swyngedouw, Marc. 2012. The federal elections in Belgium, June 2010. Electoral Studies 31(2), 448-452 
Acemoglu, Daron \& Johnson, Simon. 2005. Unbundling Institutions. Journal of Political Economy, 113(5), 949-995

Acemoglu, Daron, Johnson, Simon \& Robinson, James A. 2001. The Colonial Origins of Comparative Development: An Empirical Investigation. American Economic Review, 91(5), 1369-1401

Acemoglu, Daron \& Robinson, James. 2012. Why Nations Fail: The Origins of Power, Prosperity, and Poverty. Crown Publishers (Random House).

Adserà, Alícia, Boix, Carles \& Payne, Mark. 2003. Are You Being Served? Political Accountability and Quality of Government. Journal of Law, Economics, \& Organization 19 (2), 445-490.

Aisen, Ari \& Veiga, Francisco José. 2013. How does political instability affect economic growth? European Journal of Political Economy 29, 151-167

Alesina, Alberto, Ozler, Sule, Roubini, Nouriel \& Swagel, Phillip. 1999. Political instability and economic growth. Journal of Economic Growth 1(2), 189-211.

Alesina, Alberto \& Zhuravskaya, Ekaterina. 2011. Segregation and the Quality of Government in a Cross Section of Countries. American Economic Review 101 (5): 1872-1911.

Angelopoulos, Konstantinos \& Economides, George. 2008. Fiscal policy, rent seeking, and growth under electoral uncertainty: theory and evidence from the OECD. Canadian Journal of Economics 41(4), 1375-1405.

Aytug, Hüseyn, Kütük, Merve MavuS, Oduncu, Arif \& Togan, Sübidey, 2017. Twenty Years of the EU-Turkey Customs Union: A Synthetic Control Method Analysis. Journal of common market studies 55(3), 419-431

Bauhoff, Sebastian, 2014. The effect of school district nutrition policies on dietary intake and overweight: A synthetic control approach. Economics and Human Biology 12, 45-55.

Beck, Thorsten \& Laeven, Luc 2006. Institution building and growth in transition economies Journal of Economic Growth, 11(2), 157-186. 
Beyers, Jan \& Bursens, Peter. 2006. The European rescue of the federal state: How Europeanisation shapes the Belgian state, West European Politics, 29(5), 1057-1078.

Bouckaert Geert \& Brans, Marleen. 2012. Governing without Government: Lessons from Belgium's Caretaker Government. Governance 25(2), 173-176.

Brans, Marleen. 2012. Continuity and change in Belgium's caretake government. European Political Science 11(1): 103-107.

Brans Marleen, Pattyn, Valérie \& Bouckaert, Geert. 2016. Taking Care of Policy in Times of Crisis: Comparative Lessons from Belgium's Longest Caretaker Government. Journal of Comparative Policy Analysis 18(5), 448-463.

Castillo, Victoria, Figal Garone, Lucas, Maffioli, Alessandro, Salazar, Lina, 2017. The causal effects of regional industrial policies on employment: A synthetic control approach. Regional Science and Urban Economics 67, 25-41.

Charron, Nicholas, Dijkstra, Lewis \& Lapuente, Víctor. 2014. Regional Governance Matters: Quality of Government within European Union Member States. Regional Studies 48(1), 6890

Charron, Nicholas, \& Lapuente, Víctor. 2013. Why Do Some Regions in Europe Have a Higher Quality of Government? The Journal of Politics 75(3), 567-82.

Davies, Emil. A. 1946. Shareholders' charter: The Cohen committee's report. The Political Quarterly 17(2), 134-142.

De Long, J. Bradford \& Shleifer. Andrei. 1993. Princes and Merchants: European City Growth before the Industrial Revolution. Journal of Law \& Economics 36(2), 671-702.

De Winter, Lieven \& Dumont, Patrick. 2008. Uncertainty and Complexity in Coalition Formation. In Kaare Strøm, K. Müller, W.C. \& Bergman, T. eds. Cabinet and Coalition Bargaining: The Democratic Life Cycle in Western Europe, Oxford: Oxford University Press, $123-158$.

Deschouwer, Kris. 2009. The politics of Belgium. Basingstoke; Palgrave Macmillan. 
Deschouwer, Kris. 2012. All levels alive. European Political Science 11(1), 108-113.

Devos, Carl \& Sinardet, Dave. 2012. Governing without a Government: The Belgian Experiment. Governance 25(2), 167-171.

Diermeier, D. \& Van Roozendaa, P. 1998. The Duration of Cabinet Formation Processes in Western Multi-Party Democracies. British Journal of Political Science. 28(4), 609-626

Dixit, Avinash. 2009. Governance Institutions and Economic Activity. American Economic Review 99 (1): 5-24.

Easterly, William. 2001. The Elusive Quest for Growth. Cambridge (MA): MIT Press.

Easterly, William \& Levine, Ross. 1997. Africa's Growth Tragedy: Policies and Ethnic Divisions. Quarterly Journal of Economics, 112(4), 1203-1250.

Economides, George \& Egger, Peter. H. 2009. The role of institutions in economic outcomes: Editorial introduction. European Journal of Political Economy 25(3), 277-279.

Efendic, Adnan, Pugh, Geoff \& Adnett, Nick. 2011. Institutions and economic performance: A meta-regression analysis. European Journal of Political Economy 27(3), 586-599.

European Commission, 2012. Macroeconomic imbalances - Belgium. Macroeconomic imbalances Belgium. European Economy Occasional papers 99, July 2012.

European Council. 2011. Council Recommendation of 12 July 2011 on the National Reform Programme 2011 of Belgium and delivering a Council Opinion on the updated Stability Programme of Belgium, 2011-2014. Official Journal of the European Union 15.7.2011 C209-1

Fatás, Antonio \& Mihov, Ilian, 2013. Policy volatility, institutions, and economic growth. The Review of Economic and Statistics, 95(2), 362-376.

FGB. 2011. Belgian Stability Program 2011-2014. Brussels; Federal Government of Belgium.

Fortunato, Piergiuseppe \& Panizza, Ugo. 2015. Democracy, education and the quality of government. Journal of Economic Growth 20(4), 333-363

Gharehgozli, Orkideh, 2017. An estimation of the economic cost of recent sanctions on Iran using the synthetic control method. Economics Letters 157, 141-144. 
Glaeser, Edward L., La Porta, Rafael, Lopez-de-Silanes, Florencio \& Shleifer, Andrei. 2004. Do institutions cause growth. Journal of Economic Growth 9(3), 271-303.

Grier, Kevin \& Maynard, Norman, 2016. The economic consequences of Hugo Chavez: A synthetic control analysis. Journal of Economic Behavior and Organization 125, 1-25.

Gurkul, Henrik \& Lach, Lukasz. 2013. Political instability and economic growth: Evidence from two decades of transition in CEE. Communist and Post-Communist Studies 46 (2), 189202.

Hall, Robert E. \& Jones, Charles I. 1999. Why do some countries produce so much more output per worker than others? Quarterly Journal of Economics 114(1), 83-116

Holmberg, Sören, Rothstein, Bo \& Nasiritousi, Naghmeh. 2009. Quality of government. What you get. Annual Review of Political Science 12(1), 135-161.

Hooghe, Marc. 2012a. Does Multi-Level Governance Reduce the Need for National Government? European Political Science 11(1), 90-95

Hooghe, Marc. 2012b. The political crisis in Belgium (2007-2011): A federal system without federal loyalty. Representation 48(1), 131-138.

Jones, Charles I. \& Romer, Paul M. 2010. The New Kaldor Facts: Ideas, Institutions, Population, and Human Capital. American Economic Journal: Macroeconomics 2(1), 224-245

Kaasa, Anneli. 2013. Governance in the European Union and Neighbouring Countries. WP5/13 Search Working Papers http://www.ub.edu/searchproject/wpcontent/uploads/2013/01/WP-5.13.pdf (downloaded July 15, 2018)

Kaufmann, Daniel, Kraay, Aart \& Zoido-Lobatón, Pablo. 2000. Governance Matters: From Measurement to Action. Finance \& Development 37(2): 10-13

Keech, William. R. \& Munger, Michael C. 2015. The anatomy of government failure. Public Choice 164(1/2): 1-42. 
Kim, Man-Keun, \& Kim, Taehoo. 2016. Estimating impact of regional greenhouse gas initiative on coal to gas switching using synthetic control methods. Energy Economics 59, $329-335$.

Knack, Stephen \& Keefer, Philip. 1995. Institutions and economic performance: crosscountry tests using alternative institutional measures. Economics \& Politics 7(3), 207-227

Kreif, Noemi, Grieve, Richard, Hangartner, Dominik, Turner, Alex James, Nikolova, Silviya, \& Sutton, Matt, 2016. Examination of the synthetic control method for evaluating health policies with multiple treated units. Health Economics 25, 1514-1528.

La Porta, Rafael, Lopez-de-Silanes, Florencio, Shleifer, Andrei \& Vishny, Robert. 1999. The Quality of Government. Journal of Law, Economics and Organization 15 (1), 222-279

Laakso, Markku \& Taagepera, Rein. 1979. "Effective” Number of Parties: A Measure with Application to West Europe. Comparative Political Studies 12(1), 3 - 27.

Louwerse, Tom \& Van Aelst, Peter. 2013. The exceptional Belgian case? Government formation duration in comparative perspective. Paper presented at the conference 'Belgium: The State of the Federation', Louvain-la-Neuve, October 2013.

Mauro, Paolo. 1995. Corruption and Growth. Quarterly Journal of Economics 110(3), 681-712.

Morgan, William T. 1946. Britain's Election: A Debate on Nationalization and Cartels. Political Science Quarterly 61(2), 222-37

Munasib, Abdu, \& Rickman, Dan S. 2015. Regional economic impacts of the shale gas and tight oil boom: A synthetic control analysis, Regional Science and Urban Economics, 50, 1-17.

North, Douglas. 1981. Growth and structural change. New York: W.W. Norton

North, Douglas. 1990. Institutions, Institutional Change and Economic Performance. Cambridge, UK: Cambridge University Press.

OECD 2011. OECD economic surveys. Belgium 2011. OECD publishing. 
Ogilvie, Sheilagh \& Carus, A. W. 2014. Institutions and economic growth in historical perspective. In Steven N. Durlauf \& Philippe Aghion, eds. Handbook of Economic Growth 2, 403-513. Elsevier.

Percoco, Merco, 2015. Heterogeneity in the reaction of traffic flows to road pricing: a synthetic control approach applied to Milan. Transportation 42, 1063-1079.

Redek, Tjaša \& Sušjan, Andrej. 2005. The Impact of Institutions on Economic Growth: The Case of Transition Economies. Journal of Economic Issues 39(4), 995-1027

Rieger, Matthias, Wagner, Natascha \& Bedi, Arjun S., 2017. Universal health coverage at the macro level: Synthetic control evidence from Thailand. Social Science and Medicine 172, 4655.

Rodríguez-Pose, Andrés \& Di Cataldo, Marco. 2015. Quality of government and innovative performance in the regions of Europe, Journal of Economic Geography 15(4), 673-706

Rodríguez-Pose, Andrés \& Garcilazo, Enrique. 2015 Quality of Government and the Returns of Investment: Examining the Impact of Cohesion Expenditure in European Regions, Regional Studies 49(8), 1274-1290

Roesel, Felix, 2017. Do mergers of large local governments reduce expenditures? Evidence from Germany using the synthetic control method. European Journal of Political Economy 50, 22-36.

Rothstein, Bo, Samanni, Marcus, \& Teorell, Jan. 2012. Explaining the Welfare State: Power, Resources vs. the Quality of Government. European Political Science Review 4(1), 1-28. Rothstein, Bo \& Teorell, Jan. 2008. What Is Quality of Government? A Theory of Impartial Government Institutions. Governance 21(2), 165-190

Sachs, Jeffrey D. 2003. Institutions Don't Rule: Direct Effects of Geography on Per Capita Income. NBER Working Paper No. 9490 
Saunders, Jessica, Lundberg, Russell, Braga, Anthony A., Ridgeway, Greg \& Miles, Jeremy., 2015. A Synthetic Control Approach to Evaluating Place-Based Crime Interventions. Journal of Quantitative Criminology 31(3), 413-434.

Smith, Adam 1776. An Inquiry into the Nature and Causes of the Wealth of Nations. London: W. Strahan and T. Cadell

Strøm, Kaare, Budge, Ian \& Michael J. Laver. 1994. Constraints on Cabinet Formation in Parliamentary Democracies. American Journal of Political Science 38(2), 303-35.

Tabellini, Guido. 2008. The scope of cooperation: Values and incentives. Quarterly Journal of Economics 123(3), 905-950.

Troupin, Steve, Steen, Trui, \& Stroobants, Jesse. 2015. Fiscal consolidation in federal Belgium International Review of Administrative Sciences 81 (3), 457-478.

Vis, Barbara, Woldendorp, Jaap \& Keman, Hans. 2012. Economic performance and institutions: Capturing the dependent variable. European Political Science Review 4(1), 73-96.

Woolbert, Robert G. 1946. Spain as an African Power. Foreign Affairs 24(4), 723-35. 
Table 1. General Election results, Belgium 2010. Distribution of votes and number of seats in the House of Representatives.

\begin{tabular}{|l|l|l|l|l|}
\hline Com & Party & $\begin{array}{l}\text { \% Votes 2010 } \\
\text { election }\end{array}$ & $\begin{array}{l}\text { Seats 2010 } \\
\text { election }\end{array}$ & $\begin{array}{l}\text { Seats 2007 } \\
\text { election }\end{array}$ \\
\hline FL & Nieuw-Vlaamse Alliantie N-VA & 17.4 & 27 & $(\mathrm{a})$ \\
\hline FR & Parti Socialiste PS & 13.7 & 26 & 20 \\
\hline FL & Christen-Democratisch en Vlaams CD\&V & 10.8 & 17 & 30 \\
\hline FR & Mouvement Réformateur MR & 9.3 & 18 & 23 \\
\hline FL & Socialistische Partij Anders sp.a & 9.2 & 13 & 14 \\
\hline FK & Open Vlaamse Liberalen en Democraten Open VLD & 8.6 & 13 & 18 \\
\hline FL & Vlaams Belang VB & 7.8 & 12 & 17 \\
\hline FR & Centre Démocrate Humaniste CDH & 5.5 & 9 & 10 \\
\hline FR & Ecolo & 4.8 & 8 & 8 \\
\hline FL & Groen! & 4.4 & 5 & 4 \\
\hline FL & Libertair, Direct, Democratisch LDD & 2.3 & 1 & 5 \\
\hline FR & Parti Populaire PP & 1.3 & 1 & (b) \\
\hline FR & Front National FN & 0.5 & 0 & 1 \\
\hline
\end{tabular}

Notes: FL: Flemish parties; FR. French-Speaking parties

(a) Nieuw-Vlaamse Alliantie formed and electoral alliance with Christen-Democratisch en Vlaams in the 2007 election, holding 5 of the 30 seats obtained by CD\&V.

(b) Parti Populaire was formed in 2009

Source: Federal Public Services Home Affairs (Belgium), and authors.

Table 2. Economic growth predictor means for real Belgium and synthetic Belgium. Averaged 1999-2009

\begin{tabular}{|l|c|c|c|}
\hline \multicolumn{1}{|c|}{ Predictors } & Belgium & Synthetic & Pool \\
\hline Ln(GDPpc_lag) & 10.25 & 10.25 & 9.59 \\
\hline low_education & 38.09 & 38.41 & 29.96 \\
\hline mid_education & 35.55 & 37.57 & 48.09 \\
\hline high_education & 26.33 & 24.03 & 20.66 \\
\hline Population_density & 341.68 & 272.03 & 170.73 \\
\hline ln(investment rate) & 3.10 & 3.11 & 3.11 \\
\hline Trade Surplus & 3.55 & 3.40 & 0.35 \\
\hline Inflation & 2.02 & 2.27 & 2.95 \\
\hline Debt & 99.81 & 52.41 & 55.27 \\
\hline
\end{tabular}

Source: Authors 
Table 3. Weight matrix. Donor Pool.

\begin{tabular}{|l|l|l|l|}
\hline \multicolumn{1}{|c|}{ Country } & Unit Weight & \multicolumn{1}{c|}{ Country } & Unit Weight \\
\hline Bulgaria & 0 & Hungary & 0 \\
\hline Czech Rep. & 0 & Malta & 0 \\
\hline Denmark & 0 & Netherlands & 0.558 \\
\hline Germany & 0 & Austria & 0 \\
\hline Estonia & 0 & Poland & 0 \\
\hline Ireland & 0 & Portugal & 0 \\
\hline Greece & 0 & Romania & 0 \\
\hline Spain & 0.196 & Slovenia & 0 \\
\hline France & 0.181 & Slovakia & 0 \\
\hline Italy & 0.008 & Finland & 0 \\
\hline Latvia & 0 & Sweden & 0 \\
\hline Lithuania & 0 & United Kingdom & 0.057 \\
\hline
\end{tabular}

Source: Authors

Table 4. GDP per capita (€): real Belgium vs. synthetic Belgium.

\begin{tabular}{ccccc}
\hline Year & Real Belgium & Synthetic Belgium & Difference & Real Belgium/Synthetic Belgium \\
\hline 2010 & 33,681 & 32,617 & 1,064 & 1.033 \\
2011 & 34,462 & 32,928 & 1,534 & 1.047 \\
2012 & 34,986 & 32,958 & 2,028 & 1.061 \\
2013 & 35,225 & 33,049 & 2,176 & 1.066 \\
2014 & 35,801 & 33,685 & 2,116 & 1.063 \\
2015 & 36,524 & 34,877 & 1,647 & 1.047 \\
\hline
\end{tabular}

Source: Authors 
Figure 1. Gross Domestic Product Growth Rate (2006-2016)

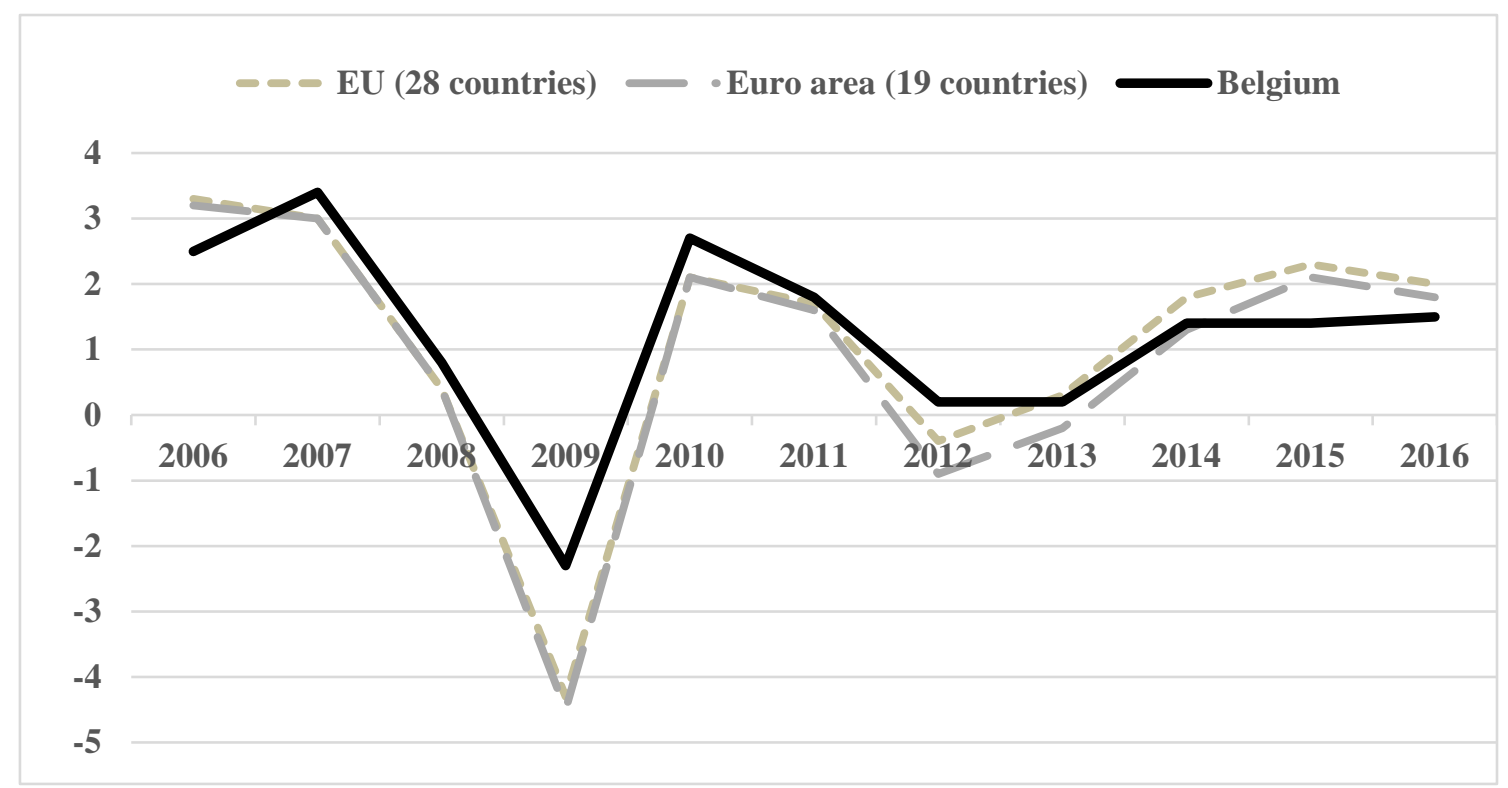

Figure 2. Trends in $\ln ($ GDP per capita): real Belgium vs. synthetic Belgium

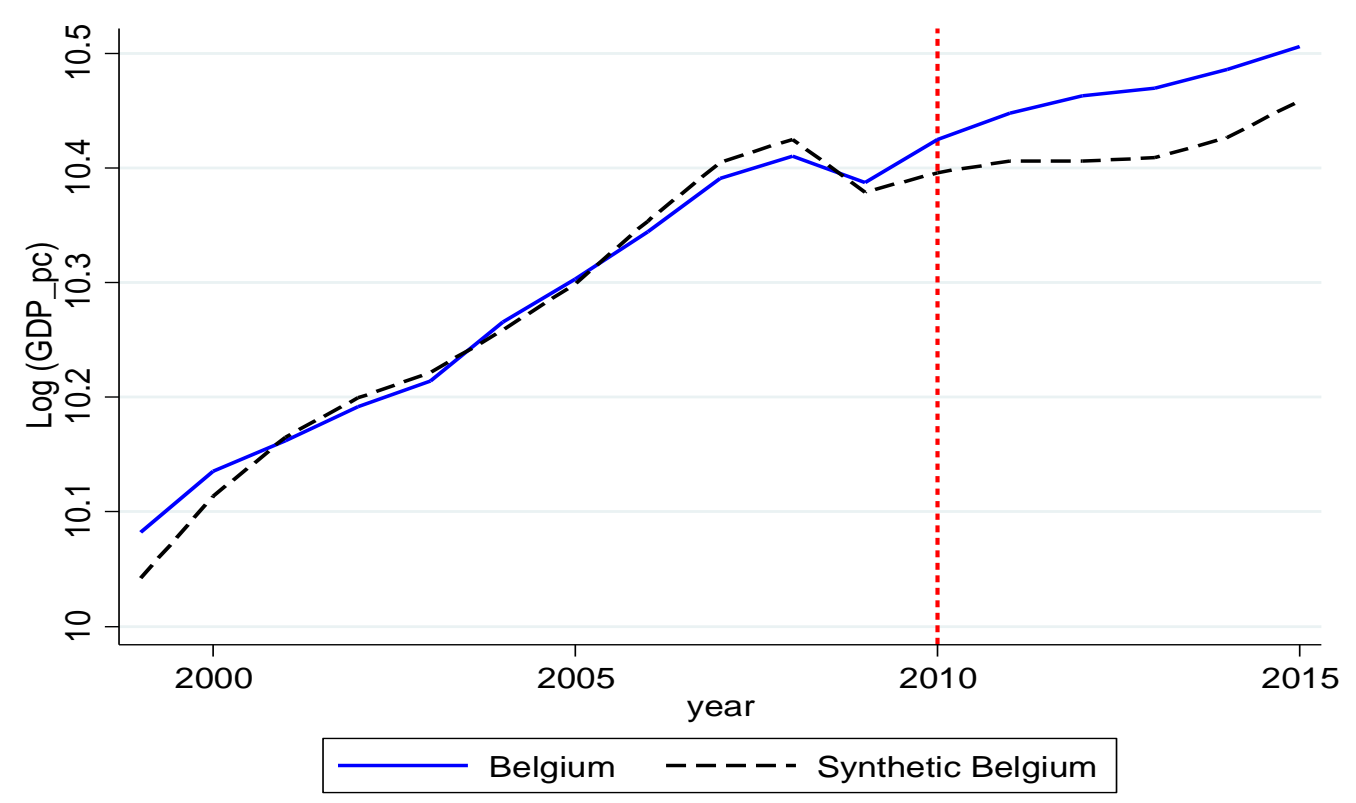


Figure 3. Gap in $\ln ($ GDP per capita): real Belgium vs. synthetic Belgium (2000-2016).

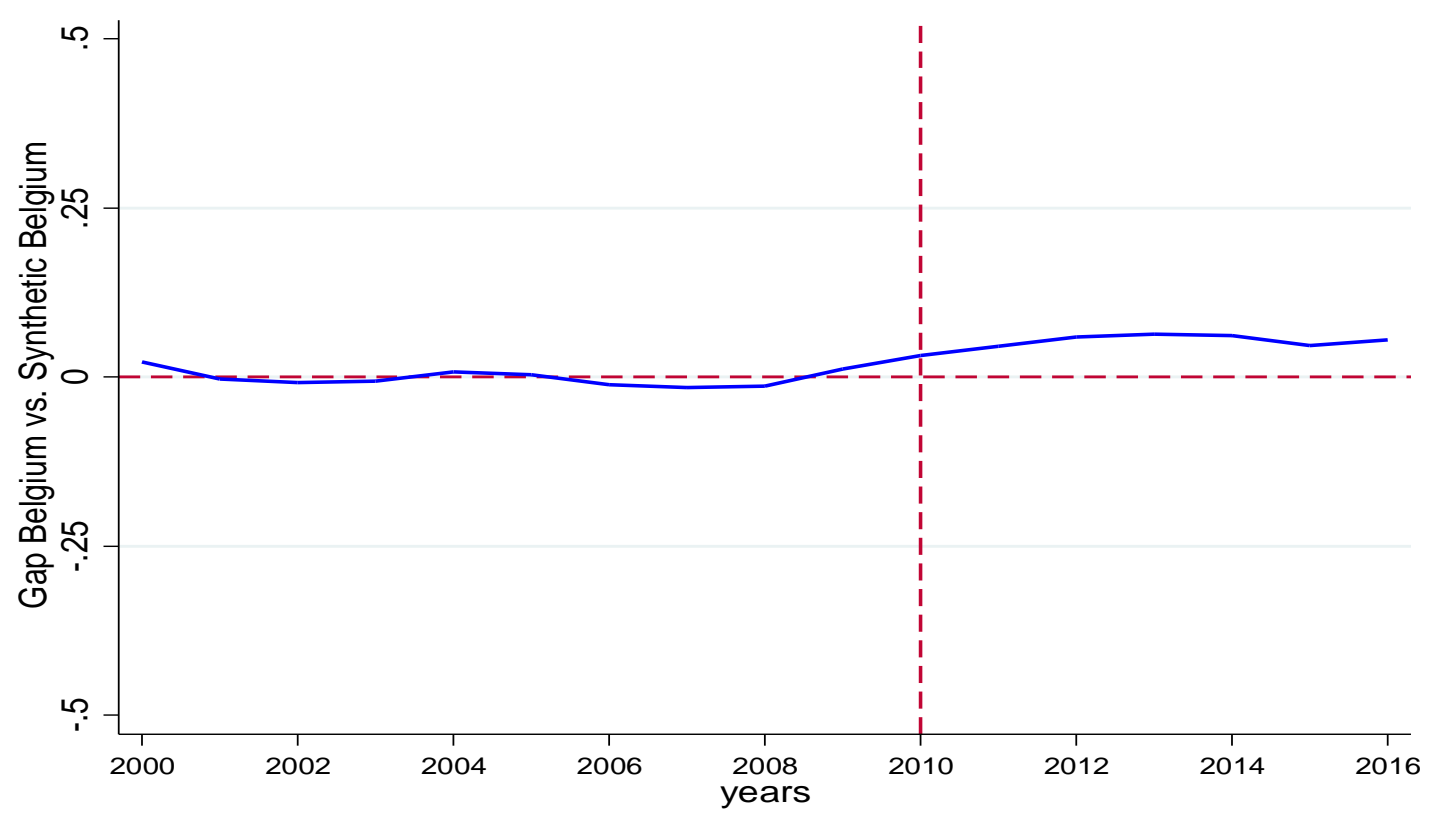

Figure 4. Placebo test ("in time”) assuming treatment effects in 2006 instead of 2010.

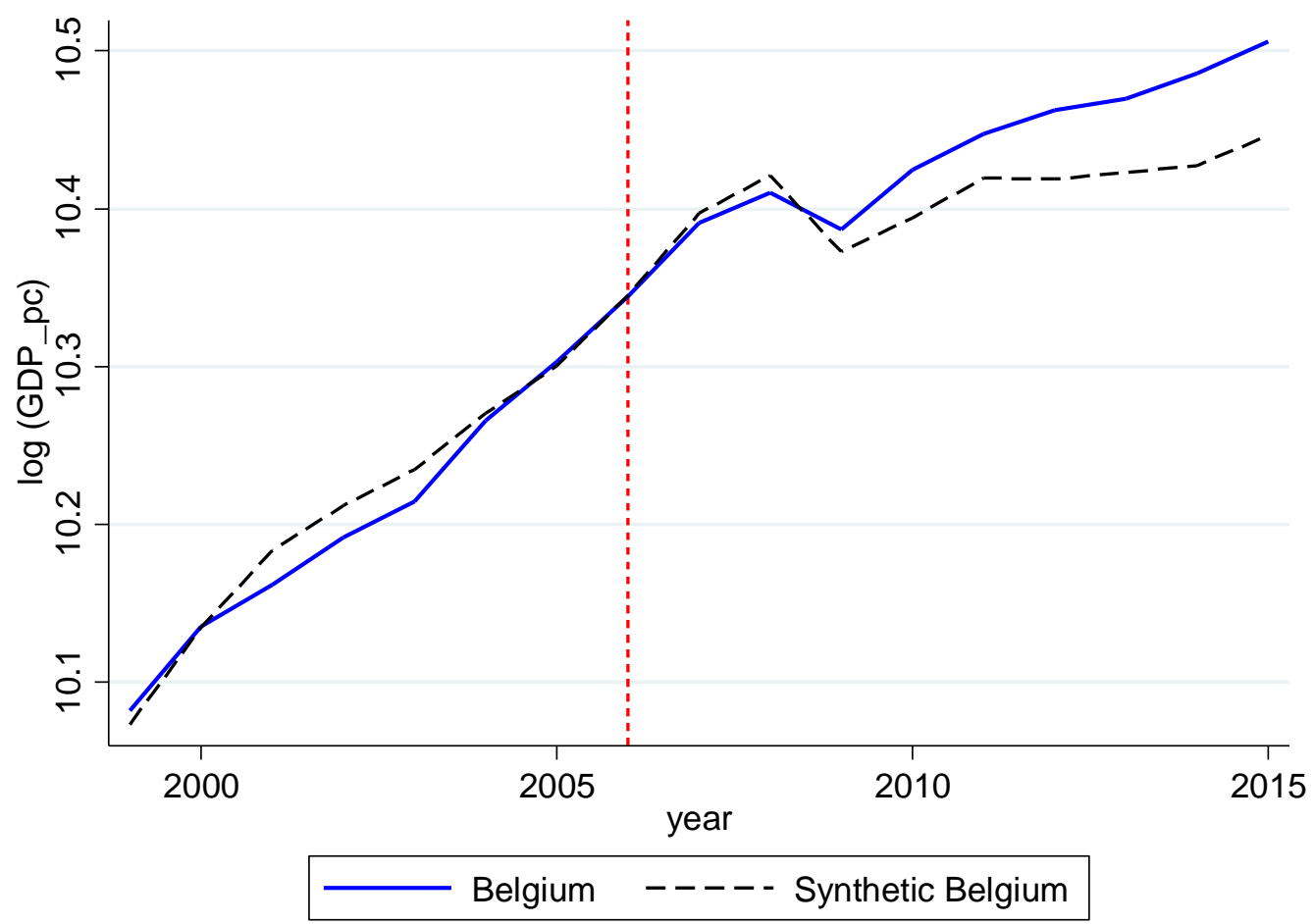


Figure 5. Placebo test ("in space") assuming treatment in non-treated countries (excluding RMSPE $>2 *$ RMSPE for Belgium).

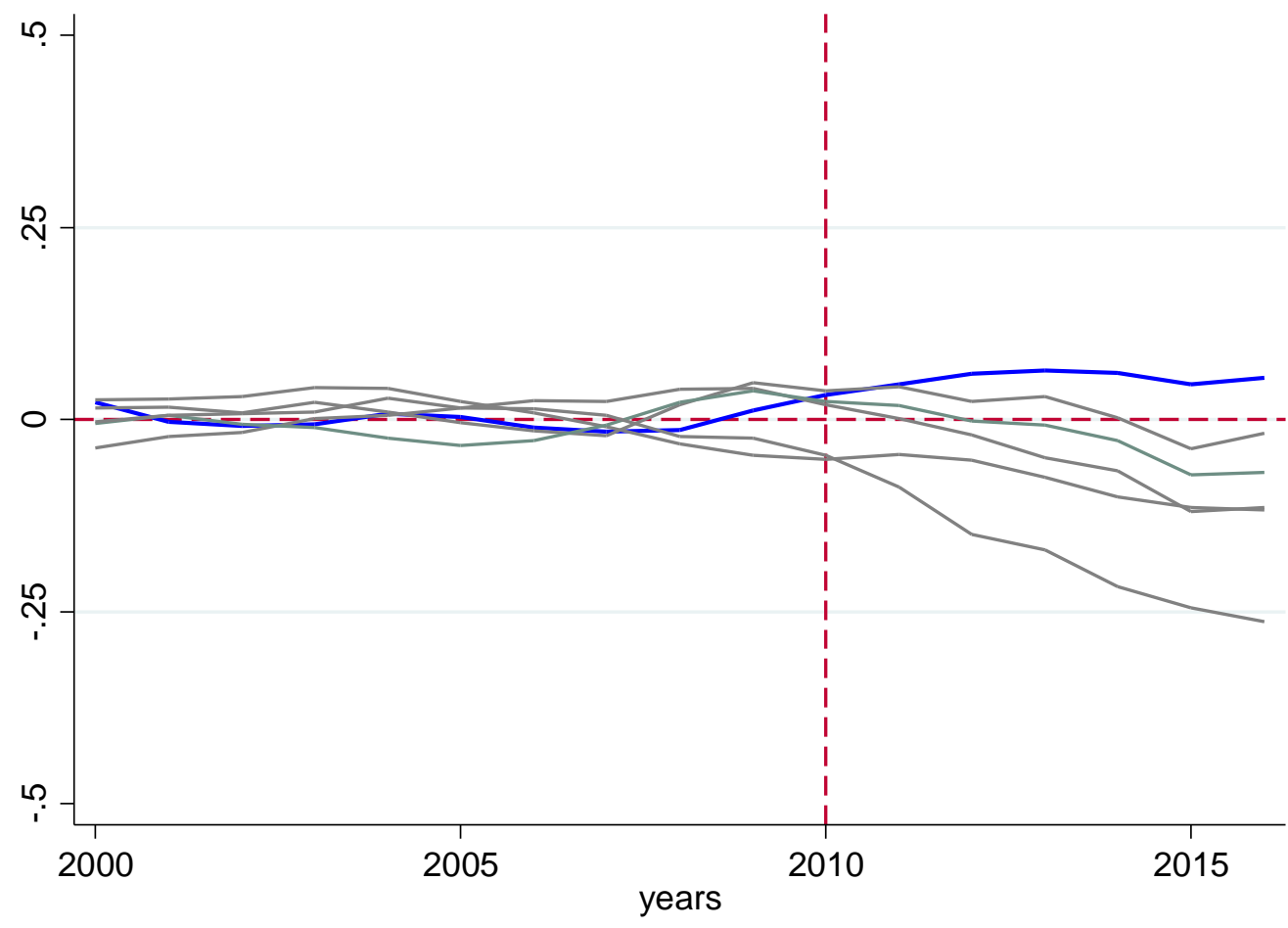

